\title{
Pollination of Cleisostoma scolopendrifolium (Orchidaceae) by megachilid bees and determinants of fruit set in southern South Korea
}

\author{
Hyun-Deok Son ${ }^{1}$, Hyoung-Tak $\mathrm{Im}^{2}$ and Sei-Woong Choi ${ }^{3^{*}}$ (1)
}

\begin{abstract}
We investigated the pollinators of Centipede's foot orchid (Cleisostoma scolopendrifolium) at five locations in southern Korea. Only one species of megachilid bee (Megachile yasumatsui) was observed at three of the sites (Mokpo, Haenam, and Wando). We assumed that the megachilid bee worked as a sole pollinator of C. scolopendrifolium based on the visiting behavior of the bees the attached pollinia. Fruits were observed at the three locations that bees visited: $74 \%$ fruit set at Mokpo, 59\% at Wando, and 31\% at Haenam. By contrast, at two of the locations where megachilid bees did not visit the plants (Naju and Jindo), there were no fruits set. The differences in fruit set rates at the three orchid populations where bees were observed appear to be related to bee abundance and flower visitation rate rather than to differences in flower abundance. The pollination interaction between C. scolopendrifolium and megachilid bees appears to involve sexual deception since only male bees were attracted to the flowers. The underlying mechanism involved in this interaction needs investigation.
\end{abstract}

Keywords: Pollinator, Cleisostoma scolopendrifolium, Megachilid bee, Fruit set, Korean peninsula

\section{Background}

The pollination ecology of orchid (Orchidaceae) has attracted the attention of many scientists including Charles Darwin. Although the majority of pollination network between animals and plants involves food rewards such as nectar and pollen to the pollinators, orchids are exceptional in that as many as one third of the 30,000 or so species achieve pollination by deception; for example, they may lure pollinators to the flower by using a food deceptive, advertising the presence of food by displaying bright colors and sweet scents (Jersakova et al. 2006; Ledford 2007). In addition, they can use sexual deception, as more than 600 species of orchids have evolved adaptations for pollination by male euglossines (Dodson et al. 1969). Euglossine-pollinated orchids produce attractive volatile compounds (terpenes and aromatics), exhibit intricate mechanisms for the attachment of

\footnotetext{
*Correspondence: choisw@mokpo.ac.kr

${ }^{3}$ Department of Environmental Education, Mokpo National University, 1666 Youngsan-ro, Chungkye-myon, Muan, Jeonnam 58554, South Korea Full list of author information is available at the end of the article
}

pollinia (pollen masses) on male bees, and lack additional floral rewards such as nectar, pollen, or pseudopollen.

In non-autogamous orchids, a single season pollinator limitation to fruit setting is strongly indicated by a low natural fruit set rate reflected by an extraordinarily high proportion of flowering individuals that do not set fruit, presumably because of a lack of pollinators (Darwin 1877). For example, Tolumnia variegate, a small twig epiphyte in the West Indies has an extremely low natural fruit set rate, often below 5\% (Ackerman and Oliver 1985). However, hand pollination results in a marked increase in fruit set, to over 70\% (Calvo 1993). Similarly, Disa tenuifolia in South Africa depends on the exploitation of instinctive foraging and territorial behavior of male megachilid bees and its fruiting success is pollinator dependent (Johnson and Steiner 1994).

Over 100 species of Cleisostoma have been reported in tropical and subtropical Asia and Australia (Wood 2014). Cleisostoma scolopendrifolium, an epiphyte orchid that grows on rocks, has been recorded on subtropical and temperate trees of Northeast Asia, 
including Korea, Japan, and China. The extent of occurrence of this species in Korea has been estimated to be $2000 \mathrm{~km}^{2}$ (National Institute of Biological Resources 2014). Each year, C. scolopendrifolium plants produce a new rhizome that ends in a vegetative shoot composed of 6-10-mm-long leaves. The inflorescence is a 1- or 2-flowered raceme, located laterally, and often shorter than leaves. In Korea, most C. scolopendrifolium flower late in July. This orchid species is self-incompatible and insect pollinated. The pollinator species of $C$. scolopendrifolium in Mokpo, South Korea, is assumed to be male megachilid bees, based on the observation that only male megachilid bees have visited the orchid and the occurrence of pollinia attached to the head of flower-visiting megachilid bees (Son et al. 2017).

There is a large body of literature describing the pollination biology of orchids worldwide. However, there is little information on the pollination ecology of orchid species in Korea. This study aimed to confirm that male megachilid bees are the unique pollinators of C. scolopendrifolium in southern Korea and to dertermine whether pollinator visitation affects the fruiting of the orchid.

\section{Materials and methods}

\section{Study sites}

In this study, we included five separate populations of Cleisostoma scolopendrifolium, all located in the southern part of the Korean peninsula: Mt. Yudalsan in the city of Mokpo (MP), Mt. Galdusan of Haenam county (HN), Gunoe-myeon of Wando county (WD), near Dado reservoir close to Naju city (NJ) and Mt. Geumgolsan of Jindo county (JD) and all in the province of Jeollanamdo (Table 1). These five sites were geographically separated. We selected sites that had orchid plants present over an area of at least $1.0 \mathrm{~m}^{2}$ because small areas with sparsely occurring flowers may affect pollinator visit frequency (Dauber et al. 2010).

\section{Pollinators}

We observed the insect visitors to each of the five separate C. scolopendrifolium sites. To estimate flower-visiting frequencies, the numbers of insects that visited flowers in each quadrat at each site were counted. Based on

Table 1 Observation sites of Cleisostoma scolopendrifolium orchid in southern South Korea

\begin{tabular}{lll}
\hline Site & Location & Patch size \\
\hline MP & Mt. Yudalsan, Mokpo City, Jeollanamdo & $2 \mathrm{~m}^{2}$ \\
WD & Sinhak-ri, Wando County, Jeollanamdo & $2 \mathrm{~m}^{2}$ \\
NJ & Near Dado Reservoir, Naju City, Jeollanamdo & $1600 \mathrm{~m}^{2}$ \\
HN & Mt. Galdusan, Haenam County, Jeollanamdo & $1.5 \mathrm{~m}^{2}$ \\
JD & Mt. Geumgolsan, Jindo County, Jeollanamdo & Distributed by patch \\
\hline
\end{tabular}

pre-study observations of the sites (Son et al. 2017), we selected the peak time of insect visits (between 9:00 and 11:00 a.m.) as the time to record insect visits. The visiting behaviors of the bee were classified into two types: "searching" and "staying." If a bee approached to a flower but only moved around and did not land, the behavior was recorded as "searching." If a bee landed on a flower and stayed on that flower for more $10 \mathrm{~s}$, the behavior was recorded as "staying" (Table 2).

\section{Determination of fruit set}

To estimate fruit sets, we monitored $1.0 \mathrm{~m}^{2}$ quadrats at each $C$. scolopendrifolium sampling site during the period in which the plant flowered and set fruit. We counted flowers of orchid populations between 19 July 2018 and 26 July 2018 and counted fruits between 11 August 2018 and 15 August 2018. The fruit set rate was measured by calculating the fruit to flower ratio in each quadrat.

\section{Results}

Is the male megachilid bee the special pollinator of $C$. scolopendrifolium?

Only male Megachile yasumatsui were observed visiting C. scolopendrifolium flowers at the MP, HN, and WD sites. Megachilid bees searched 68 flowers and stayed on 19 flowers at MP, searched 28 flowers and stayed on 6 flowers at WD and searched 11 flowers and stayed on 3 flowers at HN. Orchid pollinia were observed to be attached to the heads of megachilid bees that searched and stayed on the orchid flowers at MP, HN, and WD (Fig. 1). No bee searched or stayed on the orchid flowers at JD. On one occasion, a honey bee was observed at NJ. No orchid pollinia were attached to the body of the honey bee at NJ.

\section{Do visit frequencies of pollinator enhance fruit set?}

Fruit setting occurred at each of the three sites where male megachilid bees visited C. scolopendrifolium plants. Fruit set rates were $74 \%$ (111 fruits among 151 flowers) at MP, 59\% (366 fruits among 620 flowers) at WD, and 31\% (171 fruits among 547 flowers) at $\mathrm{HN}$. The $C$.

Table 2 Fruit set rates and bee visit behavior at five Cleisostoma scolopendrifolium sites. For site information, see Table 1

\begin{tabular}{|c|c|c|c|c|c|c|}
\hline \multirow[t]{2}{*}{ Site } & \multirow{2}{*}{$\begin{array}{l}\text { No. of } \\
\text { flowers }\end{array}$} & \multirow{2}{*}{$\begin{array}{l}\text { No. of } \\
\text { fruits }\end{array}$} & \multirow{2}{*}{$\begin{array}{l}\text { Fruit set } \\
(\%)\end{array}$} & \multirow{2}{*}{$\begin{array}{l}\text { Visitor } \\
\text { species }\end{array}$} & \multicolumn{2}{|c|}{ No. of flower visited } \\
\hline & & & & & Searching & Staying \\
\hline $\mathrm{MP}$ & 151 & 111 & 74 & Megachile yasumatsui & 67 & 16 \\
\hline WD & 620 & 366 & 59 & Megachile yasumatsui & 28 & 6 \\
\hline $\mathrm{HN}$ & 547 & 171 & 31 & Megachile yasumatsui & 11 & 3 \\
\hline NJ & 488 & 0 & 0 & Apis mellifera & 1 & 1 \\
\hline$J D$ & 166 & 0 & 0 & - & - & - \\
\hline
\end{tabular}



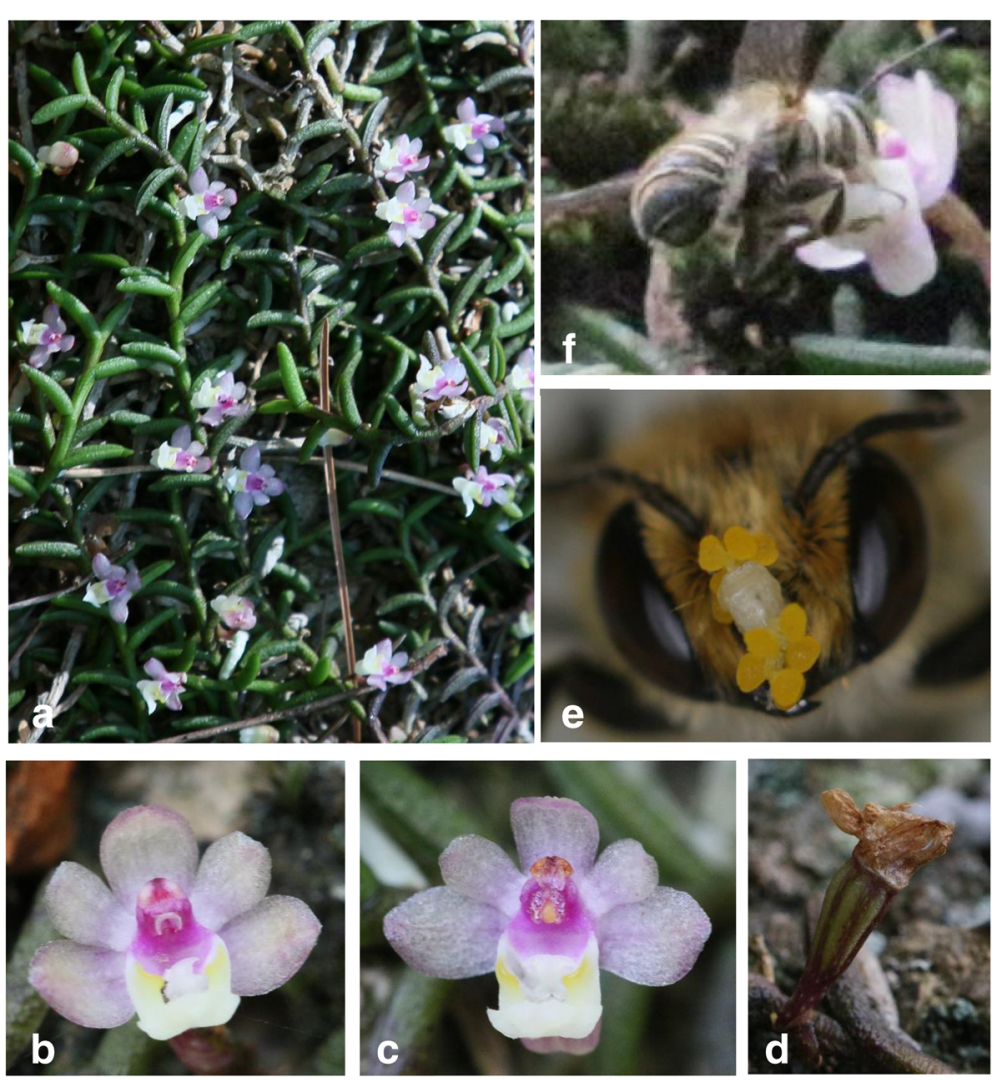

Fig. 1 Life history of Cleisostoma scolopendrifolium and male megachilid bee pollinator in southern South Korea. a. Orchid population at Wando. b. Pollinia matured. c. After pollination. d. Fruit. e. Pollinia attached to the bee head. f. Megachilid bee pollinator visitation

scolopendrifolium plants observed at NJ and JD, where no megachilid bees were observed, failed to produce fruit (Table 2).

\section{Discussion}

Based on our observation, the specific pollinators of Korean C. scolopendrifolium orchid are male megachilid bees (Megachile yasumatsui), and the fruit production process between this bee and $C$. scolopendrifolium is assumed to be a specialized one. Mendel (1995) suggested that fruit set in outcrossing orchids in their natural habitat is generally limited by pollinator availability. Pollinator visits to flowers enhance subsequent fruiting and enable outcrossing orchid populations to live longer. We observed a wide range of fruit set rates (31\% to $74 \%$ ) in three locations (MP, WD, and $\mathrm{HN}$ ) and no fruit sets at two orchid locations (NJ and JD) where no megachilid bees were observed. The frequency of visits by potential pollinators is low in many orchids (Darwin 1877; Ackerman 1981) and is the main cause of low fruit set rates. An experiment using hand pollination of orchids showed higher fruit set rates than in open pollination (Calvo 1993). For example, the orchids Cremastra appendiculata and Cymbidium goeringii showed low fruit set rates in natural condition $(1.3-2.0 \%$ and $0.4-$ $0.6 \%$, respectively), but artificial self-pollination and geitonogamous pollination produced fruit set rates of $95.7 \%$ and $96.6 \%$, respectively, for C. appendiculata, and $95.5 \%$ and $95.6 \%$, respectively, for C. goeringii. The extremely low fruit set rates observed in these two orchid species under natural conditions has been explained as the result of pollinator limitation (Chung 2004).

Fruit sets were present at three of the orchid observation sites (MP, WD, and $\mathrm{HN}$ ), but there was a wide range in fruit set rates. The patch sizes of the three observed orchid sites were similar $\left(1.5-2 \mathrm{~m}^{2}\right)$, but the numbers of flowers at WD (620) and HN (547) were notably higher than that at MP (151). Flower searching behavior of megachilid bees was most commonly observed at MP (67 searches) followed by that at WD (28 searches) and HN (11 searches). However, the proportion of bees showing flower staying after searching at these three locations were not notably different: $23.9 \%(\mathrm{MP}), 27.3 \%(\mathrm{HN})$, and $21.4 \%$ (WD), respectively. The differences in fruit set rates at the three orchid locations where bees were observed appear to be related to bee abundance and flower visitation rate rather than to differences in flower abundance. 
The orchid family is exceptional for its unusually high frequency of non-rewarding species compared to that in other plant families (Jersáková et al. 2006). Generally, food deception is the most common pollinationrelated mechanism in non-rewarding orchids (reported in 38 genera) followed by sexual deception (18 genera) (Jersáková et al. 2006). Nearly all species of the Mediterranean orchid genus Ophrys are pollinated by means of sexual deception of the pollinator (Pouyanne 1917; Kullenberg 1961; Paulus and Gack 1990). The flowers of such orchids mimic the female members of the pollinator species, usually solitary bees and wasps, and only male members are attracted to and try to copulate with the flower's labellum. During such "pseudocopulations," pollinia become attached to the bees and are transferred during further visits of the males to other flowers (Schiestl 2005). Schiestl and Cozzolino (2008) found that Ophrys attracts male bees by mimicking female mating signals through a combination of species-specific imitation female sex pheromones and unsaturated hydrocarbons (alkenes). The flowers of $C$. scolopendrifolium have very attractive bright colors, such as yellow, red, and white, but there is no food reward for the visiting pollinators due to the absence of nectar. Based on the absence of food deception, and because only male bees were attracted to the flowers, the specific pollination interaction between C. scolopendrifolium and megachilid bees involves sexual deception. The underlying mechanism of this interaction needs further experiments to elucidate the chemical ecology of the bee-flower relationship.

\section{Conclusion}

In this study, we observed that pollinator visitation affected the fruit production of C. scolopendrifolium, an outcrossing orchid. Pollinator absence can result in fruit failure while a high number of pollinator visits can result in a high production of fruit. Based on the zero fruiting rate at the NJ and JD sites, where the orchid population sizes were large, it is expected that the genetic diversity of those orchid populations will decline rapidly unless there is an increase in visits by legitimate pollinator. In a similar situation, the Saitama Primula is in danger of species extinction because the specific pollinator is reported to be absent (Yoshida et al. 2009). Therefore, understanding the pollinator's population size and pollination behaviors are of fundamental importance for the conservation of C. scolopendrifolium in Korea.

\section{Abbreviations}

HN: Haenam County, Jeollanamdo, South Korea; JD: Jindo County, Jeollanamdo, South Korea; MP: City of Mokpo, Jeollanamdo, South Korea; NJ: City of Naju, Jeollanamdo, South Korea; WD: Wando County, Jeollanamdo, South Korea

\section{Acknowledgements}

We thank the Cultural Heritage Administration and ministry of Environment, Korea for allowing to access and examine the endangered orchid plant.

\section{Funding}

This research was supported by Basic Science Research Program through the National Research Foundation of Korea (NRF) funded by the Ministry of Science and ICT (NRF - 2017R1D1A2B03028800).

\section{Availability of data and materials}

The datasets used and/or analyzed during the current study are available from the corresponding author (Dr. Sei-Woong Choi, choisw@mokpo.ac.kr) on reasonable request.

\section{Authors' contributions}

HDS and HTI observed and analyzed the pollinator's behavior and orchid biology data regarding the flowering and fruiting. SWC interpreted the data set and was a major contributor in writing the manuscript. All authors read and approved the final manuscript.

Ethics approval and consent to participate Not applicable.

Consent for publication

Not applicable.

\section{Competing interests}

The authors declare that they have no competing interests.

\section{Publisher's Note}

Springer Nature remains neutral with regard to jurisdictional claims in published maps and institutional affiliations.

\section{Author details}

${ }^{1}$ Mokpo Natural History Museum, Mokpo 58699, South Korea. ${ }^{2}$ Department of Biological Sciences, Chonnam National University, Gwangju 61186, South Korea. ${ }^{3}$ Department of Environmental Education, Mokpo National University, 1666 Youngsan-ro, Chungkye-myon, Muan, Jeonnam 58554, South Korea.

Received: 23 November 2018 Accepted: 25 December 2018 Published online: 09 January 2019

\section{References}

Ackerman JD. Pollination biology of Calypso bulbosa var. occidentalis (Orchidaceae): a food-deception system. Madrono. 1981;28:101-10.

Ackerman JD, Oliver JCM. Reproductive biology of Oncidium variegatum: moon phases, pollination, and fruit set. Amer Orchid Soc Bull. 1985;4:326-9.

Calvo RN. Evolutionary demography of orchids: intensity and frequency of pollination and the cost of fruiting. Ecology. 1993;74:1033-42.

Chung MY. Population genetics of several orchid and tree species in Korea. Implications for conservation and ecology. Jinju: Gyeongsang National University; 2004.

Darwin C. The various contrivances by which orchids are fertilised by insects 1984 edition. Chicago: University of Chicago Press; 1877.

Dauber J, Biesmeijer JC, Gabriel WE, Kunin E, Lamborn B, et al. Effect of patch size and density on flower visitation and seed set of wild plants: a pan-European approach. J Ecol. 2010;98:188-196.

Dodson CH, Dressler RL, Hills HG, Adams RM, Williams NH. Biologically active compounds in orchid fragrance. Science. 1969;164:1243-9.

Jersáková JS, Johnson D, Kindlmann P. Mechanisms and evolution of deceptive pollination in orchids. Biol Rev. 2006;81:219-35.

Johnson SD, Steiner KE. Pollination by megachilid bees and determinants of fruitset in the Cape orchid Disa tenuifolia. Nord J Bot. 1994;14:481-6.

Kullenberg B. Studies in Ophrys pollination. Zool Bidrag Uppsala. 1961;34:1-340. Ledford H. The flower of seduction. Nature. 2007:445:816-7.

Mendel G. The genetics of orchid pollination. In: Cingel NAVD, editor. An atlas of orchid pollination. European orchid: Brookfield: A.A. Balkema publishers; 1995. p. $47-52$.

National Institute of Biological Resources. Korean red list of threatened species. 2nd ed. Incheon: National Institute of Biological Resources; 2014. 
Paulus HF, Gack C. Pollinators as prepollinating isolation factors: evolution and speciation in Ophrys (Orchidaceae). Isr J Bot. 1990;39:43-79.

Pouyanne A. La fecundation des Ophrys par les insectes. Hist Nat Afr Nord. 1917; 8:6-7.

Schiestl FP. On the success of swindle: pollination by deception in orchids. Naturwissenschaften. 2005;92:255-64.

Schiestl FP, Cozzolino S. Evolution of sexual mimicry in the orchid subtribe orchidinae: the role of preadaptation in the attraction of male bees as pollinators. BMC Evol Biol. 2008;8:27. https://doi.org/10.1186/1471-2148-8-27.

Son HD, Im HT, Choi SW. Study on the pollinator and pollination mechanism of an endangered orchid species, Sarcanthus scolopendrifolius Makino (Orchidaceae) in Korea. J Apic. 2017;32:199-203.

Wood J. Cleisostoma: Distribution. In: Pridgeon AM, Cribb PJ, Chase MW, Rasmussen F, editors. Genera Orchidacearum: volume 6: Epidendroideae (part three). Oxford: Oxford University Press; 2014.

Yoshida Y, Honjo M, Kitamoto N, Ohsawa R. Reconsideration for conservation units of wild Primula sieboldii in Japan based on adaptive diversity and molecular genetic diversity. Genet Res. 2009;91:225-35.

Ready to submit your research? Choose BMC and benefit from:

- fast, convenient online submission

- thorough peer review by experienced researchers in your field

- rapid publication on acceptance

- support for research data, including large and complex data types

- gold Open Access which fosters wider collaboration and increased citations

- maximum visibility for your research: over $100 \mathrm{M}$ website views per year

At BMC, research is always in progress.

Learn more biomedcentral.com/submissions 